\title{
INDONESIAN MUSLIM IDENTITY CONSTELLATION IN THE DIGITAL MEDIA: LABELING ARROGANT ISLAM BY PERMADI ARYA ON SOCIAL MEDIA
}

Perdana Putra Pangestu

Program Pascasarjana Universitas Islam Negeri Sunan Kalijaga, Yogyakarta email : perdanaputrapangestu@gmail.com

Abstract: The emergence of various negative religious prototypes and labels has become an increasingly problematic tempest in Indonesia. Especially in Islam, dedicating meaning to a particular topic and model of the diversity of groups has recently been public hot discussions. The presence of social media creates a constellation of national narratives that have various contents. In this case, the researcher will formulate how the interactions that occur in society, especially on social media, are related to the verdict in the form of symbols addressed to certain religious models. The researcher starts with terms such as "Islam Radikal" and "Islam Arogan" which are specifically used by Permadi Arya in showing his reaction to the public on religious opinions on social media. This study uses a qualitative approach by collecting Permadi Arya's digital record data on social media as the primary source of the analysis. The data analysis was carried out by conducting collaborative topics on the model diversity of issues with the concept of Cyber Religion and Symbolic Interaction. This study revealed that the contestation to show a certain ideology on social media has also sparked various responses in the form of various identities and stigma attachments. Especially in the term "Islam Arogan" which is directed at Permadi Arya to groups with a ultra-conservative religious and radical model.

الملخص :ذشأة النماذج المتنوعة والشعائر الدينية السلبية يكون مشكلات زادت بلات بها الصراعات في إندونيسيا. وخاصة في الإسلام، في الأيام الجارية إطلاق النتيجة للموضوع زائر 
المعين وفوذج خلاف المجموعة المعينة يحل محل الحوار الدافئ، فضلا بحضور الوسائل الإجتماعية الإفتراضية، يشكل الجدال النصي في المرحلة الوطنية ذا المحتويات المتعددة. وفي هذا الأمر، لخص الباحث كيفية بناء التواصل بين أيدي الهجتمع، خاصة في الوسائل الإجتماعية، تعلقا بالتحكم في شكل الرموز الهادفة إلى نوع من المجموعة المتنوعة المعينة.

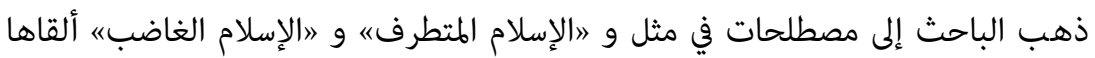
برمادي أريا في عرض رده على التعليقات الدينية المورودة في الوسائل الإجتماعية. اعتمد الباحث فيه المنهج الكيفي باستخدام سيراته الذاتية الرقمية في الوسائل الإجتماعية كبيانات أساسية ومصادرها المبدئية. وتحليلها يجري على اختلاط الموضوع بالإشاعة التنوعية في ضوء التدين الرقمي والتواصل السيمائي. وحصل هذا البحث نتيجته بكشف أن طريقة النزاع لعرض الأفكار الدينية المعينة في الوسائل الإجتماعية تشعل نار الردود في شكل نشاة

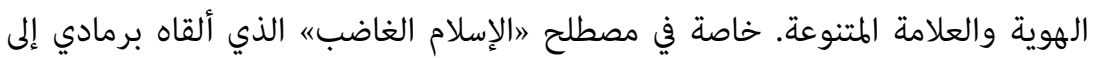
المجموعة ذات أسلوب التدين المتشدد و المتطرف.

Abstrak: Munculnya berbagai prototipe serta label keagamaan yang negatif menjadi sebuah prahara yang kian problematik di Indonesia. Khususnya dalam agama Islam, pemberian makna terhadap suatu topik dan model keberagamaan kelompok tertentu menduduki porsi perbincangan hangat publik akhir-akhir ini. Terutama dengan hadirnya media sosial berbasis daring, membuat sebuah konstelasi narasi berskala nasional yang mempunyai muatan yang beragam. Dalam hal ini, Peneliti akan merumuskan bagaimana konstruksi interaksi yang terjadi di masyarakat, khususnya di media sosial, terkait dengan vonis berupa simbolsimbol yang dialamatkan pada model keberagamaan tertentu. Peneliti bertolak pada istilah-istilah seperti "Islam Radikal" dan "Islam Arogan" yang secara spesifik dilayangkan oleh Permadi Arya dalam penunjukan reaksinya kepada publik terhadap opiniopini keagamaan di media sosial. Penelitian ini menggunakan pendekatan secara kualitatif dengan penggunaan data rekam digital Permadi Arya di media sosial sebagai basis pokok dalam sumber primer analisis Peneliti. Analisis data dilakukan dengan melakukan kolaborasi topik terhadap isu-isu model keberagamaan dengan konsep Cyber Religion dan Interaksi Simbolik. Penelitian ini berhasil mengungkap bahwasannya kontestasi untuk menunjukkan ideologi keagamaan tertentu di 
media sosial turut memantik pelbagai respon berupa munculnya identitas dan tempelan stigma yang variatif. Khususnya pada term "Islam Arogan" yang diarahkan Permadi Arya pada kelompok dengan model keberagamaan secara keras dan radikal.

Keywords: Muslim Identity, Islam Arrogant, Social Media, Permadi Arya.

\section{INTRODUCTION}

Lately, there have been massive social phenomena that label religious issues with certain terms. Religion in the context of community interaction plays a significant position in the influence of the religious model and the formation of one's identity. The resulting scenario model also varies; there are products of human interaction with religion that show positive and negative trends. ${ }^{1}$ Sometimes the labels are a component to generalize certain individuals/groups to become an identity which is actually considered detrimental to the image of a religion, especially Islam. Religion can be placed on two different poles. First, religion actually acts as a tool to construct a form of identity in humans. This implication arises because it is motivated by the doctrinal narrative of religion which tends to conceptualize a model of human spirituality to explore the teachings to which it is committed. Second, religion on the other hand is also considered an obstacle to the formation of human identity. As this can be drawn from the perspective of the meaning that religion presents limitations for humans to be able to independently form their personal characteristics and identity. ${ }^{2}$

Such complex interactions are increasingly blaring when faced with current realities, such as media of information technology. One of the media referred to here is in the digital-based social segment and can be accessed via the internet network (online). Social media can actually be used as a tool to present a humanist and peaceful religion to the public in the context of personal and collective interests.

\footnotetext{
1 Steward Harrison Oppong, "Religion and Identity," American International Journal of Contemporary Research 3, no. 6 (2013): 11.

2 Pamela Ebstyne King, "Religion and Identity: The Role of Ideological, Social, and Spiritual Contexts," Applied Developmental Science 7, no. 3 (2003): 210.
} 
Social media can also be a tool for making various counter narratives presented to people who defame religious values. This capacity can be used as an analytical medium for humans to make corrections to the values and ethics of their environment. ${ }^{3}$ In normative terms, social media is an artificial booth that can be accessed to share ideas/ideas, seek information about actual issues, and interact with the wider social sphere. This allows users to get to know the outside world which is covered by complex dialectics and ideologies. Thus, social media seems to be a diorama of a representation of the vast world. ${ }^{4}$

However, social media users cannot be separated from blunders that result in a disconnection from the previously encountered realities. In general, this is due to the various identities of the outside world, so that users who make the "blunder" feel shocked and cannot reduce the context of a more comprehensive understanding. As a result, various stigmas and negative labels appeared to legitimize the blunder, as previously mentioned. This is very unfort unate, because social media as a functional tool as a means of seeking information, especially about Islam, has instead become a stirring of various narratives that can no longer be classified sacred and profane. ${ }^{5}$ At a more crucial stage, social media can be used by buzzers with tendentious and provocative interests, such that in a broader momentum it can damage national unity and cause chaos. Thus, social media is also a place for fear of bad interactions and the potential to pollute Islamic teachings in particular, and Bhinneka in general. ${ }^{6}$

Judging by the diversity of "Islamic" interactions in Indonesia that have occurred lately, especially on social media, has prompted the author to conduct in-depth studies. This study was carried out through a qualitative research base that reviewed the analysis of digital data literature. The objective of this research is to highlight the phenomenon of labeling "Radical Islam" (Islam Radikal) in general and "Arrogant Islam" (Islam Arogan) by the social influencer,

3 Ebstyne King, 198.

4 Ridwan Rustandi, "Cyberdakwah: Internet Sebagai Media Baru Dalam Sistem Komunikasi Dakwah Islam," NALAR: Jurnal Peradaban Dan Pemikiran Islam 3, no. 2 (2019): 86-87.

5 Slavomir Galik, "Cyber-Spirituality as a New Form of Religion," European Journal of Science and Theology 11, no. 6 (2015): 12.

6 Jeff Zaleski, Spiritualitas Cyberspace: Bagaimana Teknologi Komputer Mempengaruhi Kehidupan Keberagamaan Manusia, 1999, 89. 
Permadi Arya or Abu Janda. The data analysis phase was carried out by reviewing Permadi Arya's digital track records obtained from his social media accounts as well as comparisons of secondary data, mainly in the timeframe related to the issue of "Islam Arogan" in the final quarter of January 2021 to the early half of February 2021. In this case, the researcher will allocate religious narratives as symptoms, systems, and social phenomena not as religious doctrine. Therefore, what appears in this study will lead to an optimal conclusion angle and can reflect various similar events. ${ }^{7}$

Elaboration in several perspectives, especially symbolic interactions, is felt to add to the narrative of understanding in responding to the phenomena being discussed. ${ }^{8}$ From here it will be known how the patterns of individual interaction with their environment are related to feedback on Islamic narratives so that the emerging label of Islam are exposed on social media and become the public conversation. This research departs from concerns and assumptions which suggest that there has been an irony in the interaction on the topic of Islam which has penetrated the public media. This is at least due to inequality and disability in responding completely to situations that are contradictory to the concept of understanding of each party.

\section{THE DISPARITY OF MUSLIM IDENTITY IN DIGITAL MEDIA}

The implementation of the construction of one's identity is now increasingly covered with various multi-problematic facts. Hall argues that the opening of an increasingly varied modern space is a platform for placing new concepts on issues regarding the transformation of human identity. ${ }^{9}$ The process of conception of the formation of the subject of an individual actor finds a fairly broad path at a more modern level. The facilities provided by technological advances can optimally function in a faster and more complex identity construction than previous conventional methods.

7 Atho Mudzhar, Pendekatan Studi Islam: Dalam Teori Dan Praktek (Pustaka Pelajar, 1998), 35.

${ }^{8}$ Herbert Blumer, Symbolic Interactionism: Perspective and Method (Univ of California Press, 1986), 3-10.

9 Stuart Hall and Paul Du Gay, Questions of Cultural Identity (Sage Publications, 1996), 110-11. 
The expansion of identity formation which is increasingly problematic, now also cannot be speculated how it will work when faced with several major factors. O'Donnel said that the speed of the times made the social dynamics that took place could not be guaranteed the optimization. This is because too many elements, such as ideology, style, ideas, and so on, are mixed in one conceptual puddle which often does not make a particular object form until it is mature. ${ }^{10}$ The tendency for such patterns to mutate in various forms. Goofman in Nasrullah even states that humans do form their concept of identity, but the substance of their identity is affected and falls into the will of their environment. ${ }^{11}$ This is a matter closely related to essential ambiguity. Because, if the human image construction pattern has the pattern mentioned by Goofman above, then the aspects related to symbols and identities that are individual or collective are just imaginary things. This is certainly not an ideal representation of autonomous identity.

Nowadays, the identical phenomenon to the explanation above intersects with advancing technological developments, especially online-based social media. The convenience obtained through efforts to overcome communication difficulties can be overcome by the presence of social media. Mc-Luhan in O'Donnel likens the modern human event in a term called Global Village. ${ }^{12}$ Global Village allows humans to interact with one another without having to care about geographical and time boundaries. One can freely assemble conceptions with others integrated into a single virtual assembly. The characteristics of the virtual assemblies in question are those that are currently massive, namely a place to bring together individuals/ groups through their respective smart screen screens. However, in relation to this discussion, the construction of identities interwoven through virtual assemblies does not always represent a perfect trend. Some of the characteristics that are used as patrons in drafting the concept of identity through communication interactions do not appear in virtual assemblies. This is one of the irony and disparity of inequality that occurs in the current interaction phenomenon. Unlike

\footnotetext{
${ }^{10}$ Kevin O’Donnel, Postmodernisme (Yogyakarta: Kanisius, 2009), 18.

${ }^{11}$ Rulli Nasrullah, "Konstruksi Identitas Muslim Di Media Baru," Komunika: Jurnal Dakwah Dan Komunikasi 5, no. 2 (2011): 222.

${ }^{12}$ O'Donnel, Postmodernisme, 18.
} 
the case with conventional encounters which require physical contact in the form of meetings. Efforts to recognize and develop identity can be obtained optimally from the characteristics of the interlocutor who is being displayed, it can be in the form of speech style, expression, use of diction, and so on.

In a more specific context, especially in the life of Muslims, the authority of a Muslim in branding and showing his identity can be manifested in an artificial platform. The realization of self-image can now be placed on a media platform that seems to represent an ideology, understanding, affiliation, and matters related to religious interaction. This representation model can be read simply through a profile photo, whether a person is wearing a scabbard, veil, or robe; or in more complex practices such as content in their social status, what da'wah material is often uploaded, who are their role models and so on. These various elements can now instantly convert the identity of a Muslim subject. An example is an attitude that is often echoed by urban Muslims who are associated with the Hijrah movement. According to Zahara, this movement is closely related to seven activity patrons that can be identified as the basis for the identity of the Hijrah group, especially when making faces on social media. ${ }^{13}$

The symptoms caused by advances in artificial technology with the issue of identity above, then undergo transfiguration at several extensive moments. This is true both on a small communal scale and on a broader basis nationally. The freedom to ground identity, to argumentative personal views, is well facilitated by social media. This kind of flexibility can then be boarded with various pragmatic and political agendas. ${ }^{14}$ This fact in its final stage becomes very crucial for the struggle of the paradigm and ideology of the Muslim community. This directly affects the diversity of values and identities that can influence social media users. This becomes very beneficial if the material consumed can play a positive role in the development of self-identity. However, it is unfortunate if negligence and inability to filter material can affect the construction of thinking and identity

${ }^{13}$ Mila Nabila Zahara, Dadan Wildan, and Siti Komariah, "Gerakan Hijrah: Pencarian Identitas Untuk Muslim Milenial Di Era Digital," Indonesian Journal of Sociology, Education, and Development 2, no. 1 (2020): 60.

${ }^{14}$ Rulli Nasrullah, "Media Baru Dan Potensi Terorisme Virtual," EMPATI: Jurnal Ilmu Kesejahteraan Sosial 1, no. 1 (2012): 65. 
which is increasingly radical. Therefore, individuals with certain characteristics (such as radicals) will show a religious patron that can be problematic in society, especially in the internal discourse of Muslims.

\section{RADICAL ISLAMIC IDENTITY PATRON}

Discussions that orbit on the topic of "Islam" and "radical" have become endless patrons and are often discussed by many researchers. The discussion referred to in it includes linkages with political issues, transnational movements, to ideological disparities within the Muslim community. However, concerning this article, the researcher will focus on "radical" as a label, as well as how these nicknames can be prominent, especially in developments in the era of social media.

At the terminological level, radicals are often equated with terrorism, even though definitively the two terms are still problematic to be juxtaposed with. It can be said that radical (ideologically) is indeed mentioned as one of the construction bases of acts of terror that have been sticking out so far. The practice of theorism is often narrated as the fruit of a deep reduction from radical (rooted; fundamental) ideology, so that the label "radical" in this dimension is defined as the various parties involved in the shadow of doctrinal interactions, namely radical ideology. This paradigm then underwent a significant evolution into a movement that was allegedly raised the legalization of Islamic Sharia in the social and even state ecosystems. ${ }^{15}$

Activists who are active in this booth often claim various names. Call it like Mujahidin, followers of the Sunnah, Sharia activists, and other terminology models, which seem to represent the objects and teachings that this group carries, namely Islam. According to Hiariej, the emphasis of "Fundamentalist" and "Radical" is reluctant to be accepted as the basis for these activists, because these two dictionaries describe a teaching concept that integrates the values in it. Similar to "Moderate Islam" and "Radical Islam", according to most communities this is irrelevant to Islamic identity because it will lead to the division of the doctrine in the internal teachings of Islam. Whereas what this faction can accept is the classification of "Muslim" and "Non-Muslim" or "Muslim" and "Kafir". This is due

${ }^{15}$ Mastori Mastori, "Islam Fundamentalis-Radikal: Stigmatisasi Atas Gerakan Formalisasi Islam," Cakrawala: Jurnal Studi Islam 15, no. 1 (2020): 56. 
to the clarity of the teachings of the texts found in Islam regarding the classification of the obedient and non-obedient subjects. ${ }^{16}$

The various identity labels that surround Muslims today, especially those related to this article, will gradually become a destructive patch. Previously, there were massive dogmatize labels that still illustrate the image of Islam which is built on the concept of conservative, degenerative teachings, and other negative terms. This will cloud and add to the increasingly negative Islamic visualization in the eyes of the global community. The embodiment of radical Islam is a necessity that actually cannot be validated in general, but seems to have become a patron which is closely related to the recognition of Islam itself. The emergence of diction which leads to the deconstruction of the image of Islam from internal and external rooms dialectically. It can be identified from various argumentative narratives that have a critical character, such as Muslim academics and scholars, as well as "oriental" parties who try to analyze the phenomenon of Muslim Jihadists. The perpetuation of the harsh events that befell the Islamic identity, over time it will stick to individual and collective identity.

When traced through long historical dynamics, especially those embedded in Muslims in Indonesia, the ontological realm of Radical Islam is not purely from within the country, but the result of external stimuli from the Middle East. This can be indicated by the style of action that is often reflected which does not manifest an Indonesian aspect. ${ }^{17}$ Jati stated that the axis that is often used as the cardinal point of the radical Islamic faction in Saudi Arabia. The basis of the Wahabi sect brought by Muhammad bin Abdul Wahab bin Sulaiman at-Tamimi (d. 1792 AD) became a model object for these circles. The offense that is used as a foothold in laying the correct axis of the Islamic model according to the Radical Islamic group is that Wahabi is the original and pure embodiment of Islam. That is, Islam, which has historically originated from Arabia, is superimposed on Wahabi as a unit of understanding and organization which also originated in

${ }^{16}$ Eric Hiariej, "Aksi Dan Identitas Kolektif Gerakan Islam Radikal Di Indonesia,” Jurnal Ilmu Sosial Dan Ilmu Politik 14, no. 2 (2010): 145-46.

${ }^{17}$ Ahmad Rizky Mardhatillah Umar, "Melacak Akar Radikalisme Islam Di Indonesia,” Jurnal Ilmu Sosial Dan Ilmu Politik 14, no. 2 (2010): 172-76. 
Arabic. This form of revival is certainly seen as the true Islam with the pure Koran and Hadith without the domination of any authority. ${ }^{18}$

Hadiz in Umar uses the term "populism" in naming the movements and models of persons involved in many events that are thick with radical movements. Because in reality, the term "populist" arises from groups that experience marginalization in the state and social ecosystems. So they try to reverse the situation by restoring the role and position of Islam with a non-bureaucratic route. Hadiz continued that the parties who are usually involved in this activity are three elements, (1) the working class experiencing repression from industrialization, (2) the middle class which has difficulty finding jobs, (3) the micro-unit that is oppressed by oligarchic subjects. Until a progressive idea emerged, all of which carried the spirit of "Islam and Jihad" in its principle of action. ${ }^{19}$

Then, Roy stated that the militant activity of some Muslims, which was actualized in this form of expression, was an effort to Islamize the indigenous population using social and political means. Roy said there were differences in the course of action chosen between the Jihadists and Modernists. If the first group is more in the ideological orbit, while the second group prioritizes acculturation and adaptive aspects by introducing the values that exist in Islam. These two dimensions both contribute to the quantitative value of Muslims, but carry a different image of quality. In this case, the coverage of Radical Islam has proven to be cornering Islam both at the social and theological level. ${ }^{20}$

In line with Roy, although the dialectic of identity embedded in terrorism, jihadists, and similar terms is closely related to Radical Islam, both must be read with a more complete concept. Equating the two diction will result in non-objectivity that exists in each discourse. Thus, Umar stated that if Radical Islam is speculated as a social problem, then what is right is not to castrate it, but also

18 Wasisto Raharjo Jati, "Islam Populer Sebagai Pencarian Identitas Muslim Kelas Menengah Indonesia," Teosofi: Jurnal Tasawuf Dan Pemikiran Islam 5, no. 1 (2015): 148.

${ }^{19}$ Vedi R. Hadiz, "Islamic Populism and Political Transition in Post-Soeharto Indonesia, Disampaikan Pada Seminar Internasional Tentang Transisi Politik Di Indonesia," Yogyakarta: Fisipol UGM, 2009.

${ }^{20}$ Olivier Roy, The Failure of Political Islam (Harvard University Press, 1996), 36. 
solve the problems of persistent disparity in the country. On the other hand, if Radical Islam is imaged as a theological problem internally in Islam, it is necessary to purify the concept that is reduced by the Muslims themselves. Because in this case, the doctrine taught by Islam in no way represents atrocities and other acts of arrogance. ${ }^{21}$ Manifestations of conflict resolution should be carried out with approaches that involve the various complexities of the current narrative, whether exclusive to the parties directly involved, or social dissemination in public media.

\section{SYMBOLS AND THEIR INTERACTIONS ON SOCIAL MEDIA}

The confusion of the label "radical" nowadays also experiences a dilemma when faced with the current context, especially those related to the world of social media. Considering that social media has touched the world of da'wah, the label has also been attached to parties by carrying a preaching style that is closely related to the term "radical". This phenomenon is preceded by a conception that precedes it, starting from the attributes and appearance, methods in rhetoric, and the material of preaching that is brought. Jati stated that there are various models that serve as the basis for legitimizing someone as part of the radical Muslim community. According to him, the categories that can be segmented into radical Islam are groups with a hardliner foundation such as HTI and MMI. Meanwhile, commodities that are born from the orbit of this understanding give birth to a model such as short pants, beard, veil, and so on. ${ }^{22}$

The above non-substantial patron classification has been found in recent times. The reconstruction of some of the preachers' groups to the understanding of religious texts brings products that become new identities for their congregations. When this product model intersects with online-based social media, it will lead to unclear conception of each person on a particular case. Simply put, generalizing behavior is now commonplace, so that when someone sees other people who use certain attributes, they will automatically be labeled with a certain identity as well. It is very possible if we meet people who are closely

\footnotetext{
${ }^{21}$ Umar, "Melacak Akar Radikalisme Islam Di Indonesia," 183.

22 Jati, "Islam Populer Sebagai Pencarian Identitas Muslim Kelas Menengah Indonesia," 149.
} 
related to the label "radical", but the attributes used do not represent the affiliation that is followed. Vice versa, there may be parties who are considered "modernists", but the attributes worn do not reflect the alliance from which they originate. This is what is called obscurity in the conception of each person.

\section{SITTING CASE IN THE ARYA PERMADI CASE}

In some cases that occur on social media, the interconnected interactions of several affiliated parties also create identical patterns. This paper will focus on the social case that befell Permadi Arya, whose full name is Heddy Setya Permadi alias Abu Janda. Abu Janda is known as a social media buzzer or social influencer who is active in responding to political and religious issues, especially radical and intolerant narratives. Abu Janda via his account @permadiaktivis1 made a controversial tweet on January 24, 2021 on Twitter, revealing that Islam is an arrogant religion. Here's the full statement along with a screenshot of the tweet, ${ }^{23}$

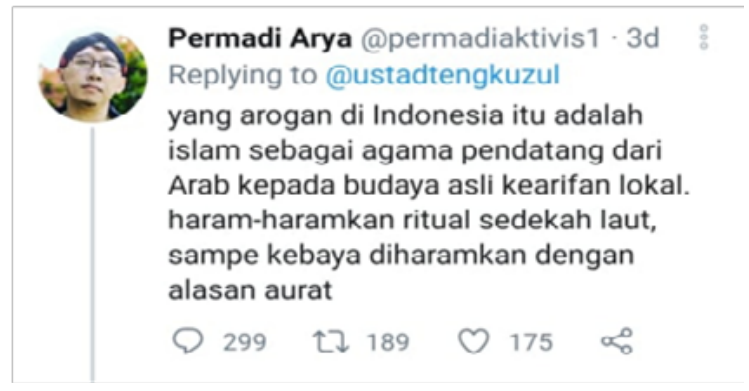

'Yang arogan di Indonesia itu adalah Islam sebagai agama pendatang dari Arab kepada budaya asli kearifan lokal. Haramharamkan ritual sedekah laut, sampai kebaya diharamkan dengan alasan aurat'. In English, 'What is arrogant in Indonesia is Islam as the religion of immigrants from Arabia to the original culture of local wisdom. Prohibition ritual of alms sea, until kebaya is forbidden on the grounds of genitals,

${ }^{23}$ Kumparan, “Abu Janda Klarifikasi soal 'Islam Arogan,” accessed April 5, 2021, https://kumparan.com/kumparannews/abu-janda-klarifikasi-soal-islam-arogan$1 \mathrm{v} 4 \mathrm{xC} 86 \mathrm{pSiM}$. 
Abu Janda's tweets clearly stated an identity that labeled Islam an "arrogant" religion. Arrogance in this context is an activity carried out by Islam as a foreign religion (from Arabic) which often cuts local wisdom such as traditions and indigenous beliefs of the Indonesian people.

Refers to Blumer's conception ${ }^{24}$ Regarding the symbolic interactions presented in this article, the author sees that there are patterns in the Abu Janda case that intersect with Blumer's idea. First, Abu Janda's independence as a social media activist has been proven through the digital footprint of his social media accounts, both from the @permadiaktivis1 account on Twitter, and the @permadiaktivis2 account on Instagram. Abu Janda is active in responding to various national-scale social events related to religious issues and pluralism. The feedback made by Abu Janda was by giving tweets and statements that were straightforward but using communicative language. In addition, Abu Janda emphatically states that he is a social media striker who actively counters provocative tweets. ${ }^{25}$ This implies that Abu Janda performed his various actions independently without tendentious repression. His cleverness in constructing public narratives on his autonomy is a representation of Blumer's idea that humans behave according to the meanings they construct. This construction is certainly built from the constellation of meanings and events consumed by Abu Janda, who then creates symbols that he thinks need to be discussed, especially topics regarding the Radical Islamic model.

Second, the birth of a meaning or a symbol is a product of the formulation of a person's interaction with the environment around him. In the case that happened to Abu Janda, the diction of "Islam Arogan" might be the point of interest in this topic. This is because diction has a close connotation with the term Radical Islam, which has previously been discussed above. The label Islam Arogan was created as an expression to address the series of events revealed in this case. First, Islam Arogan was born from Tengku Zulkarnain's statement through the account @ustadtengkuzul (Abu Janda's

${ }^{24}$ Blumer, Symbolic Interactionism.

${ }^{25}$ Deddy Corbuzier, Abu Janda Hanya Disini!! Debat Habis $\square$ Di Maafkan $\square$ Exclusive -Deddy Corbuzier Podcast, 2021, https://www.youtube.com/ watch?v=19IenoiqAZ4. 
interlocutor) in addressing the incidents of arrogant minorities in South Africa. Below is the full statement and screenshots from Tengku Zulkarnain's tweet, ${ }^{26}$

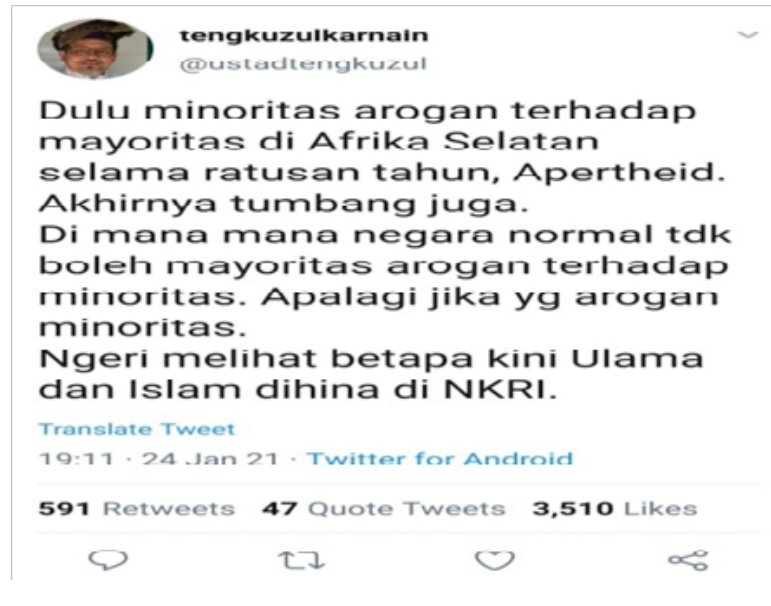

In English, 'In the past, minoties were arrogant towards the majority in South Africa for hundreds of years, apertheid. finally collapsed too. Everywhere a normal country should not be the majority arrogant towards the minority. especially if that is an arrogant minority. horrified to see how now Ulama and Islam are insulted in the Republic of Indonesia'

Second, Islam Arogan appears in a new meaning that was raised by Abu Janda by giving a response to Islam Arogan which forbids local traditions and wisdom. ${ }^{27}$ From this, it can be seen that the dichotomy of the meaning is the result of interaction between parties which results in the diversity of meanings of Arogan Islam. It is proven that the label is relevant to the construction of Blumer's idea, which states that symbols and meanings are built on human interaction with their environment.

Third, the situation and conditions that are currently emerging also affect the mobility of interactions regarding certain meanings. Blumer's statement became more easily actualized in the context of

\footnotetext{
${ }^{26}$ Kumparan, "Abu Janda Klarifikasi soal 'Islam Arogan.”"

${ }^{27}$ Kompas Cyber Media, "Abu Janda Diperiksa Bareskrim, Jelaskan soal 'Tweet'-nya Halaman all," KOMPAS.com, accessed February 20, 2021, https:// nasional.kompas.com/read/2021/02/01/21382461/abu-janda-diperiksa-bareskrimjelaskan-soal-tweet-nya.
} 
the case experienced by Abu Janda. This is due to a variant of the topic that has often aired in the past two years, concerning religious issues, especially Islam. This symptom can be seen since the 2019 Presidential election was vigorously segmented on the issues of Islamic groups carried by each camp with their respective labels. If this hegemony can be brought down to date and raises new idioms in reality, including Islam Arogan. In addition, the tendency of preaching social media by some preachers who are often associated with the conservative group's puddle is about legal content. This point of view is often chosen because of the increasingly biased activities of modern Muslims, which according to some of these groups are far from kaffah Islamic teachings. So, when the content of the proselytizing of the law by these groups intersects with the cultural context that is claimed to be syncretized, haram or prohibition of it will emerge. This is where the stereotype of Arogan Islam can be considered reconstructed through the interaction of the situation taking place in recent public realities.

\section{CONCLUSION}

Interpersonal dynamics models in religious topics produce various responses in the form of the emergence of various identities and stigma attachments. The development of advanced technology, such as social media, adds to the dialogue of the community by establishing interactions and branding their respective identities, both personal and pragmatic. From the Permadi Arya case, the label he gave focus of a certain issue, namely about "ArrogantRadical Islam", in his perspective. This proves that the collection of interactions has prompted Permadi Arya to respond to issues of violence and arbitrariness in the name of religion in his statement "Arogan Islam". Such patterns will become increasingly massive if narrative contestations on the basis of promoting identity are increasingly prevalent in the social media. Therefore, it is necessary to elaborate increasingly dynamic concepts by researchers to highlight such phenomena. 


\section{REFERENCES}

Blumer, Herbert. Symbolic Interactionism: Perspective and Method. Univ of California Press, 1986.

Corbuzier, Deddy. Abu Janda Hanya Disini!! Debat Habis. Di Maafkan Exclusive -Deddy Corbuzier Podcast, 2021. https:// www.youtube.com/watch?v=19IenoiqAZ4.

Ebstyne King, Pamela. "Religion and Identity: The Role of Ideological, Social, and Spiritual Contexts." Applied Developmental Science 7, no. 3 (2003): 197-204.

Galik, Slavomir. "Cyber-Spirituality as a New Form of Religion." European Journal of Science and Theology 11, no. 6 (2015): 5-14.

Hadiz, Vedi R. "Islamic Populism and Political Transition in PostSoeharto Indonesia, Disampaikan Pada Seminar Internasional Tentang Transisi Politik Di Indonesia." Yogyakarta: Fisipol UGM, 2009.

Hall, Stuart, and Paul Du Gay. Questions of Cultural Identity. Sage Publications, 1996.

Hiariej, Eric. "Aksi Dan Identitas Kolektif Gerakan Islam Radikal Di Indonesia.” Jurnal Ilmu Sosial Dan Ilmu Politik 14, no. 2 (2010): 131-68.

Jati, Wasisto Raharjo. "Islam Populer Sebagai Pencarian Identitas Muslim Kelas Menengah Indonesia." Teosofi: Jurnal Tasawuf Dan Pemikiran Islam 5, no. 1 (2015): 139-63.

Kumparan. “Abu Janda Klarifikasi soal 'Islam Arogan.” Accessed April 5, 2021. https://kumparan.com/kumparannews/abujanda-klarifikasi-soal-islam-arogan-1v4xC86pSiM.

Mastori, Mastori. "Islam Fundamentalis-Radikal: Stigmatisasi Atas Gerakan Formalisasi Islam." Cakrawala: Jurnal Studi Islam 15, no. 1 (2020): 54-66.

Media, Kompas Cyber. "Abu Janda Diperiksa Bareskrim, Jelaskan soal 'Tweet'-nya Halaman all." KOMPAS.com. Accessed February 20, 2021. https://nasional.kompas.com/ 
$\mathrm{read} / 2021 / 02 / 01 / 21382461 / \mathrm{abu}$-janda-diperiksa-bareskrimjelaskan-soal-tweet-nya.

Mudzhar, Atho. Pendekatan Studi Islam: Dalam Teori Dan Praktek. Pustaka Pelajar, 1998.

Nasrullah, Rulli. "Konstruksi Identitas Muslim Di Media Baru." Komunika: Jurnal Dakwah Dan Komunikasi 5, no. 2 (2011): 221-34.

—. "Media Baru Dan Potensi Terorisme Virtual." EMPATI: Jurnal Ilmu Kesejahteraan Sosial 1, no. 1 (2012): 59-70.

O’Donnel, Kevin. Postmodernisme. Yogyakarta: Kanisius, 2009.

Oppong, Steward Harrison. "Religion and Identity." American International Journal of Contemporary Research 3, no. 6 (2013): 10-16.

Roy, Olivier. The Failure of Political Islam. Harvard University Press, 1996.

Rustandi, Ridwan. "Cyberdakwah: Internet Sebagai Media Baru Dalam Sistem Komunikasi Dakwah Islam." NALAR: Jurnal Peradaban Dan Pemikiran Islam 3, no. 2 (2019): 84-95.

Umar, Ahmad Rizky Mardhatillah. "Melacak Akar Radikalisme Islam Di Indonesia.” Jurnal Ilmu Sosial Dan Ilmu Politik 14, no. 2 (2010): 169-86.

Zahara, Mila Nabila, Dadan Wildan, and Siti Komariah. "Gerakan Hijrah: Pencarian Identitas Untuk Muslim Milenial Di Era Digital." Indonesian Journal of Sociology, Education, and Development 2, no. 1 (2020): 58-70.

Zaleski, Jeff. Spiritualitas Cyberspace: Bagaimana Teknologi Komputer Mempengaruhi Kehidupan Keberagamaan Manusia, 1999. 